\title{
Partisipasi Aktif Mahasiswa dalam Proses Pembelajaran Profesi Keguruan
}

\section{Agus Kichi Hermansyah*, Dewi Puji Rahayu, Ratna Purwanty, Yonarlianto Tembang}

\author{
Jurusan Pendidikan Guru Sekolah Dasar, Universitas Musamus, Indonesia \\ * Corresponding Author. E-mail: aguskichi@unmus.ac.id
}

\begin{tabular}{|l|l|l|}
\hline Receive: $12 / 08 / 2020$ & Accepted: $17 / 10 / 2020$ & Published: $12 / 11 / 2020$ \\
\hline
\end{tabular}

\begin{abstract}
Abstrak
Penelitian ini bertujuan untuk mendeskripsikan partisipasi aktif mahasiswa dalam proses pembelajaran pada mata kuliah Profesi Keguruan di Jurusan Pendidikan Guru Sekolah Dasar, Universitas Musamus Merauke. Subjek penelitian ini adalah mahasiswa PGSD Unmus yang mengambil mata kuliah Profesi Keguruan. Objek penelitian ini adalah partisipasi aktif mahasiswa. Pendekatan yang digunakan dalam penelitian ini ialah pendekatan kualitatif. Data penelitian ini adalah lembar observasi, dan dokumentasi. Data dianalisis melalui reduksi data, penyajian data, dan penarikan kesimpulan penelitian. Hasil observasi pembelajaran oleh dosen observer pada penerapan model pembelajaran jigsaw penilaian dosen observer sebesar 96\% kategori sangat aktif, penilaian mahasiswa sebesar $82,14 \%$ kategori sangat aktif. Sedangkan untuk pembelajaran dengan model pembelajaran konvensional diperoleh hasil penilaian observer sebesar 52\% dengan kategori cukup aktif, dan hasil penilaian mahasiswa menunjukkan persentase sebesar 45,31\% dengan kategori cukup aktif.
\end{abstract}

Kata Kunci: partisipasi aktif mahasiswa; profesi keguruan; kualitatif.

\section{Active Student Participation in Teacher Professional Learning Processess}

\begin{abstract}
This study aims to describe the active participation of students in the learning process in the Teaching Profession course in the Department of Primary School Teacher Education, Musamus University, Merauke. The subjects of this study were PGSD Unmus students who took the Teaching Profession class. The object of this research is the active participation of students. The approach used in this research is a qualitative approach. The data of this study are observation sheets, and documentation. Data were analyzed through data reduction, data presentation, and research conclusions. The results of observations of learning by observer lecturers on the application of the jigsaw learning model observer lecturer assessment of $96 \%$ were very active categories, student assessments by $82.14 \%$ were very active categories. Whereas for learning with conventional learning models the observer assessment results obtained by $52 \%$ with the category of moderately active, and the results of the assessment of students showed a percentage of $45.31 \%$ with the category of quite active.
\end{abstract}

Keywords: active student participation; teaching profession; qualitative. 


\section{Pendahuluan}

Proses pembelajaran merupakan proses perubahan tingkah laku yang terjadi dalam proses pembelajaran[1]. Perubahan tingkah laku tersebut meliputi perubahan knowledge, attitude, dan skills [2]. Perubahan tersebut bersifat menetap yang dihasilkan melalui latihan dan pengalaman. Proses belajar mahasiswa yang terjadi bersifat individual, artinya ialah secara individu mahasiswa melakukan pembelajaran [3]. Proses pembelajaran tersebut pada hakekatnya ialah suatu proses interaksi yang terjadi antara mahasiswa dengan dosen, mahasiswa dengan mahasiswa, mahasiswa dengan sumber belajar, maupun mahasiswa dengan lingkungan di sekitarnya [4].

Tingkat partisipasi mahasiswa dalam proses pembelajaran sangat diperlukan [5]. Terlebih bagi mahasiswa yang mengambil jurusan kependidikan sebagai calon pendidik. Sebagai calon pendidik, tentunya mahasiswa perlu untuk menguasai bukan hanya kompetensi pedagogik, sosial, emosional dan keprofesionalan, melainkan calon guru perlu untuk memiliki kepercayaan diri yang baik. Kepercayaan diri diperlukan untuk mendukung empat kompetensi yang harus dimiliki oleh seorang guru yang profesional [6]. Untuk mendapatkan kompetensi tersebut, mahasiswa diharuskan mengambil matakuliah profesi keguruan. Mata kuliah profesi keguruan mencakup materi konsep profesi, syarat-syarat profesi, kode etik profesi, organisasi profesi, profesi pendidik dan tenaga kependidikan, kualifikasi dan kompetensi, jenis-jenis pendidik dan tenaga kependidikan, kode etik pendidik dan tenaga kependidikan, pembinan karir pendidik dan tenaga kependidikan dan organisasi kependidikan.

Partisipasi mahasiswa dapat diartikan sebagai segala bentuk aktifitas mahasiswa dalam proses pembelajaran di kelas [1]. Melihat fenomena yang marak terjadi dengan menerapkan pembelajaran menggunakan berbagai metode pembelajaran, dirasa masih belum mampu untuk mengakomodir tingkat partisipasi aktif mahasiswa dalam pembelajaran [2]. Mahasiswa cenderung memilih diam di kelas dengan pasif menerima materi pembelajaran yang disampaikan. Tidak adanya inisiatif mahasiswa dalam proses pembelajaran mengakibatkan randahnya partisipasi aktif mahasiswa.

Pembelajaran pada paradigma baru menghendaki adanya kegiatan belajar yang dilakukan oleh peserta didik [7]. Pengajar ataupun dosen lebih berperan sebagai fasilitator dalam kegiatan pembelajaran. Pada hakekatnya, pembelajaran yang efektif dan efisien adalah pembelajaran yang dapat membangkitkan partisipasi aktif sehingga tujuan pembelajaran yang dicapai dapat tercapai dengan baik [8]. Dengan melibatkan partisipasi aktif mahasiswa dalam proses pembelajaran, secara tidak langsung memberikan pembelajaran kepada mahasiswa untuk dapat menjadi calon guru yang memiliki kepercayaan diri yang baik, selain memiliki kompetensi lain yang harus dimiliki.

Penelitian ini dapat terselesaikan berdasarkan penelitian terdahulu yang telah dikaji oleh peneliti. Di antara penelitian terdahulu ialah penelitian yang melihat tingkat partisipasi aktif siswa dalam pembelajaran di kelas [9], [10], [11], [12], [13], [14]. Penelitian tersebut menunjukkan adanya partisipasi aktif siswa sebagai dampak diberlakukannya suatu model pembelajaran. Partisipasi aktif pula terlihat dari hasil penelitian lainnya yang menyebutkan bahwa terdapat partisipasi aktif siswa dengan menggunakan media pembelajaran dan memanfaatkan lingkungan sebagai sumber belajar siswa [15].

Melihat begitu pentingnya tingkat partisipasi aktif mahasiswa, maka penelitian ini diharapkan dapat memberikan gambaran kepada peneliti lainnya untuk dijadikan referensi terhadap penelitian selanjutnya. Sehingga peneliti melihat kebermanfaatan terhadap kajian partisipasi aktif mahasiswa pada 
pembelajaran profesi keguruan Pendidikan Guru Sekolah Dasar.

\section{Metode}

Penelitian ini adalah penelitian kualitatif [16]. Bentuk penelitian ini adalah deskriptif kualitatif dengan metode pengumpulan data melalui observasi [17]. Penelitian ini mendeskripsikan atau menggambarkan partisipasi aktif mahasiswa dalam mengikuti mata kuliah Profesi Keguruan di jurusan PGSD, Universitas Musamus.

Subjek penelitian ini adalah mahasiswa yang mengambil mata kuliah Profesi Keguruan. Pemilihan kelas pada mata kuliah tersebut dilakukan karena sebagian besar mahasiswa ialah orang asli Papua. Alasan lainnya yakni mata kuliah ini merupakan mata kuliah dasar bagi seluruh mahasiswa PGSD untuk mendapatkan kompetensi sebagai calon guru yang profesional. Mata kuliah ini mengajarkan kompetensi yang berkaitan dengan profesi keguruan.

Setelah data terkumpul melalui observasi, selanjutnya data dikaji menggunakan analisis deskriptif kualitatif yang terdiri dari: reduksi data, penyajian data, dan kesimpulan [17]. Data hasil observasi dan penilaian mahasiswa disajikan secara jelas dan alamiah. Kemudian, setelah melakukan seluruh proses penelitian diperolehlah deskripsi tentang partisipasi aktif mahasiswa dalam proses Profesi Keguruanpada jurusan PGSD, Unmus.

\section{Hasil dan Pembahasan}

Perkuliahan dilakukan dengan menggunakan pembelajaran sesuai dengan rencana yang telah disusun oleh dosen pengampu mata kuliah dengan menerapkan model pembelajaran konvensional dan model kooperatif tipe jigsaw. Pada Pembelajaran Jigsaw, pelaksanaan pembelajaran diawali dengan melakukan: doa dan presensi, apersepsi (mengulas materi yang akan disampaikan dengan materi yang telah diketahui oleh mahasiswa), menyampaikan indikator pembelajaran, dan memberikan pengantar tentang materi pembelajaran. Pada kegiatan inti, dosen menjelaskan secara singkat materi perkuliahan, membagi topik pembelajaran menjadi empat bagian (kelompok ahli), masing-masing kelompok mendiskusikan topiknya. Masing-masing kelompok menentukan pembagian orang ke-1, ke-2, dst untuk masuk dalam kelompok belajar. Masing-masing anggota kelompok belajar menyampaikan topiknya dan mendiskusikannya. Mahasiswa kembali ke kelompok ahli untuk saling diskusi. Kegiatan penutup berupa membuat kesimpulan, evaluasi, refleksi, dan tindak lanjut.

Sementara untuk pembelajaran konvensional kegiatan pembelajaran dimulai dengan doa, presensi, penyampaian tujuan pembalajaran dan penyampaian tujuan. Pada kegiatan inti, dosen menyampaikan materi perkuliahan dengan ceramah dan tanya jawab. Pembelajaran lebih terlihat motonon dengan partisipasi mahasiswa rendah. Kegiatan penutup berupa membuat kesimpulan bersama dan memberikan tugas kepada mahasiswa. Pada pembelajaran dengan menggunakan model pembelajaran konvensional diperoleh data sebagai berikut: aktifitas mahasiswa cenderung cukup aktif dengan perolehan persentase hanya sebesar 45,32. Penilaian dosen observer pada pembelajaran melalui penerapan model pembelajaran konvensional hanya sebesar 52\% dengan kategori cukup aktif.

Dari hasil penilaian yang diberikan oleh mahasiswa pada pembelajaran jigsaw diikuti oleh sebanyak 36 mahasiwa, diperoleh data sebagai berikut: (a) Apakah anda merasa senang mengikuti pembelajaran seperti ini? Mahasiswa yang menjawab sangat setuju sebanyak 11 orang, dan setuju 25 orang, (b) Apakah anda merasa lebih aktif dengan belajar seperti ini? Mahasiswa yang menjawab sangat setuju 11 orang, setuju 24 orang, dan tidak setuju 1 orang, (c) Apakah anda lebih cepat memahami konsep materi pembelajaran dengan belajar seperti ini? Mahasiwa yang 
menjawab sangat setuju sebanyak 7 orang, setuju 26 orang, dan tidak setuju 3 orang, (d) Apakah anda lebih bersemangat belajar sehingga persentase keaktifan mahasiswa ialah 82,14 persen dengan kategori sangat aktif.Hasil evaluasi tersebut dapat

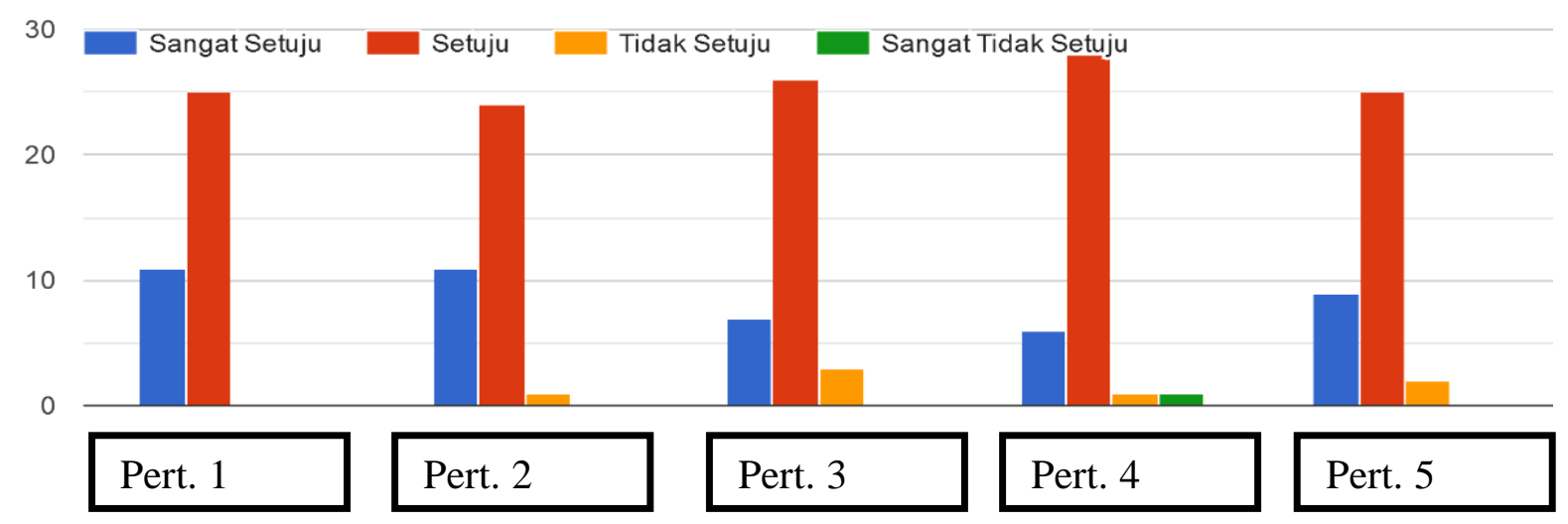

Diagram 1. Hasil Evaluasi Pelaksanaan Pembelajran dengan Penerapan Model Pembelajaran Kooperatif Tipe Jigsaw

dengan metode pembelajaran seperti ini? Mahasiswa yang menjawab sangat setuju 6 orang, setuju 28 orang, tidak setuju 1 orang, dan sangat tidak setuju 1 orang, dan (e) Apakah anda berani mengemukakan pendapat dengan belajar seperti ini? Mahasiswa yang menjawab sangat setuju sebanyak 9 orang, setuju 25 orang, dan tidak setuju 2 orang. Secara singkat hasil penilaian tersebut dapat digambarkan pada Tabel berikut.

Tabel 1. Hasil

PenilaianPembelajaranmelaluiPenerapan Model PembelajaranKooperatifTipe Jigsaw

\begin{tabular}{ccccc}
\hline \multirow{2}{*}{ Soal } & \multicolumn{4}{c}{ PilihanJawaban } \\
& SS & S & TS & STS \\
\cline { 2 - 5 } 1 & 11 & 25 & - & - \\
2 & 11 & 24 & 1 & - \\
3 & 7 & 26 & 3 & - \\
4 & 6 & 28 & 1 & 1 \\
5 & 9 & 25 & 2 & - \\
Total & $44 \times 4$ & $128 \times 3$ & $7 \times 2$ & $1 \times 1$ \\
Skor Total & \multicolumn{5}{c}{$576+384+14+1=575$} \\
Persentase & $575 / 700 * 100=82,14$ \\
\hline
\end{tabular}

Berdasarkan Tabel 1 di atas dapat dilihat hasil penilaian yang diberikan mahasiswa diperoleh hasil jawaban yakni: 44 menjawab sangat setuju, 128 setuju, 7 tidak setuju, dan 1 sangat tidak setuju. Dari hasil tersebut diperoleh total skor 575, digambarkan pada Diagram 1 berikut ini:

Selain penilaian yang diberikan oleh mahasiswa terhadap proses pembelajaran jigsaw, dibantu pula oleh seorang dosen yang bertindak sebagai observer untuk menilai jalannya proses perkuliahan. Dosen yang bertindak sebagai observer ialah ibu Dewi Puji Rahayu, S.Pd., M.Pd. Hasil observasi yang telah dilakukan dapat ditunjukkan sebagai berikut: (a) Mengucapkan salam pembukan (sangat aktif), (b) Apersepsi; menjawab pertanyaan dosen (sangat aktif), (c) Menyimak penyampaian tujuan pembelajaran (sangat aktif), (d) Menyimak pemberian pengantar materi oleh dosen (sangat aktif), (e) Mengikuti pemberian materi oleh dosen (sangat aktif), (f) Partisipasi mahasiswa (aktif), (g) Memberikan simpulan (sangat aktif), (h) Evaluasi; menjawab pertanyaan dosen (sangat aktif), (i) Refleksi; memberikan tanggapan (aktif), dan (f) Menjawab salam penutup (sangat aktif). Dari jawaban tersebut dapat digambarkan pada Tabel 2.

Berdasarkan Tabel 2, diperoleh hasil yakni 8 soal menjawab sangat aktif dengan skor 5, dan 2 soal menjawab kurang aktif dengan skor 4 sehingga total skor 48 . Dari total skor tersebut diperoleh persentase yaitu total skor dibagi skor maksimal dikali 100 menjadi: $48 / 50 * 100=96 \%$ dengan 
kategori sangat aktif.Untuk model pembelajaran konvensional diperoleh hasil penilaian pelaksanaan pembelajaran yang diikuti oleh sebanyak 31 Mahasiswa ialah sebagai berikut: (a) Apakah anda merasa senang mengikuti pembelajaran seperti ini? Sebanyak 25 orang menjawab tidak setuju, dan 6 orang sangat tidak setuju, (b) Apakah anda merasa lebih aktif dengan belajar seperti ini? Sebanyak 23 orang menjawab tidak setuju, dan 8 orang sangat tidak setuju.

Tabel 2. Hasil Observasi Pembelajaran melalui Penerapan Model Pembelajaran Kooperatif tipe Jigsaw

\begin{tabular}{|c|c|c|c|c|c|}
\hline \multirow[b]{2}{*}{ Soal } & \multicolumn{5}{|c|}{ PilihanJawaban } \\
\hline & $\begin{array}{l}\text { SA } \\
\text { (5) }\end{array}$ & $\begin{array}{c}\text { A } \\
(4)\end{array}$ & $\begin{array}{c}\text { CA } \\
\text { (3) }\end{array}$ & $\begin{array}{r}\mathbf{K A} \\
(2)\end{array}$ & $\begin{array}{l}\text { TA } \\
\text { (1) }\end{array}$ \\
\hline 1 & 5 & & & & \\
\hline 2 & 5 & & & & \\
\hline 3 & 5 & & & & \\
\hline 4 & 5 & & & & \\
\hline 5 & 5 & & & & \\
\hline 6 & & 4 & & & \\
\hline 7 & 5 & & & & \\
\hline 8 & 5 & & & & \\
\hline 9 & & 4 & & & \\
\hline 10 & 5 & & & & \\
\hline Total & 40 & 8 & - & - & - \\
\hline Skor Total & & & 48 & & \\
\hline Persentase & & & $50 * 10$ & 96 & \\
\hline
\end{tabular}

Untuk poin (c) Apakah anda lebih cepat memahami konsep materi pembelajaran dengan belajar seperti ini? Sebanyak 24 orang menjawab tidak setuju, dan 7 orang menjawab sangat tidak setuju, (d) Apakah anda lebih bersemangat belajar dengan metode pembelajaran seperti ini? Sebanyak 24 orang menjawab tidak setuju, dan 7 orang menjawab sangat tidak setuju, dan (e) Apakah anda berani mengemukakan pendapat dengan belajar seperti ini? Sebanyak 1 orang menjawab sangat setuju, 1 orang menjawab setuju, 25 orang menjawab tidak setuju, dan 4 orang menjawab sangat tidak setuju. Secara singkat hasil penilaian tersebut dapat digambarkan pada Tabel 3 berikut.

Tabel 3. Hasil

PenilaianPembelajaranmelaluiPenerapan Model PembelajaranKonvensional

\begin{tabular}{ccccc}
\hline \multirow{2}{*}{ Soal } & \multicolumn{4}{c}{ PilihanJawaban } \\
& SS & S & TS & STS \\
\cline { 2 - 5 } 1 & - & - & 25 & 6 \\
2 & - & - & 23 & 8 \\
3 & - & - & 24 & 7 \\
4 & - & - & 24 & 7 \\
5 & 1 & 1 & 25 & 4 \\
Total & $1 \times 4$ & $1 \times 3$ & $121 \times 2$ & $32 \times 1$ \\
Skor Total & \multicolumn{5}{c}{$4+3+242+32=281$} \\
Jumlah & \multicolumn{5}{c}{$281 / 620 * 100=45,32$} \\
\hline
\end{tabular}

\begin{tabular}{lr}
\multicolumn{1}{c}{ BerdasarkanTabel } & di \\
atasdapatdilihathasilpenilaian & yang \\
diberikanmahasiswadiperolehhasiljawabany \\
akni: 1 menjawabsangatsetuju, 1 setuju, 121 \\
tidaksetuju, dan 32 sangattidaksetuju. Dari \\
hasiltersebutdiperoleh total skor 281 , \\
sehinggapersentasekeaktifanmahasiswaiala \\
h 45,32 \\
persendengankategoriCukupAktif.Hasil
\end{tabular}

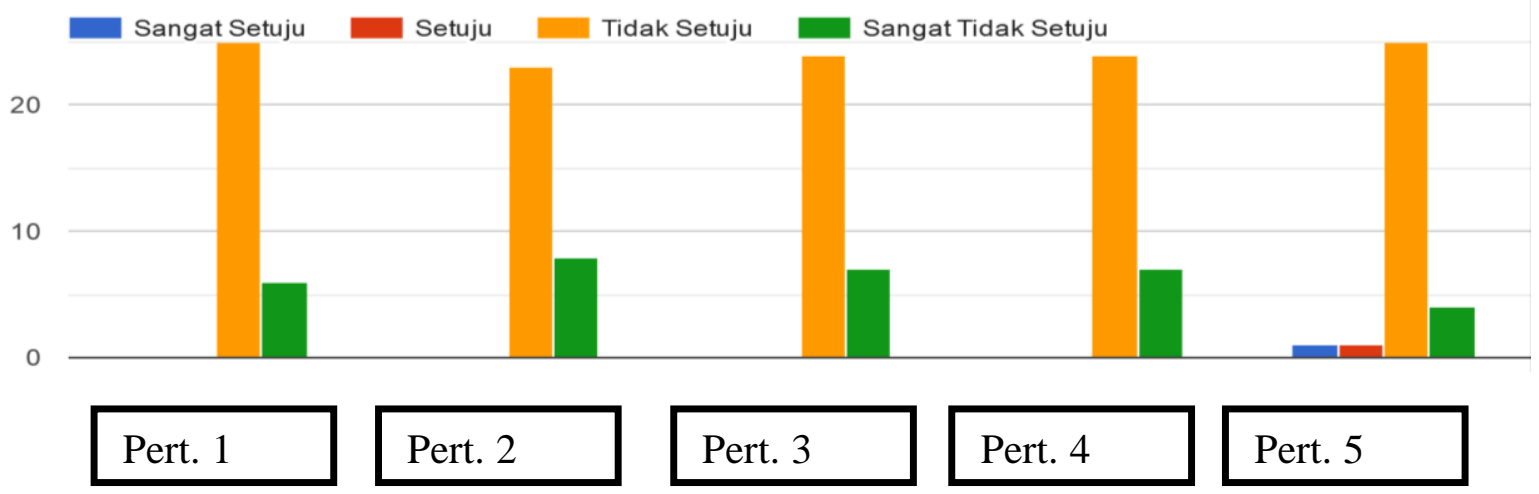

Diagram 2. Hasil Evaluasi Pelaksanaan Pembelajran dengan Penerapan Model Pembelajaran Konvensional 
evaluasitersebutdapatdigambarkan pada Diagram 2.

Selain penilaian yang diberikan oleh mahasiswa terhadap proses pembelajaran konvensional, dibantu pula oleh seorang dosen yang bertindak sebagai observer untuk menilai jalannya proses perkuliahan. Hasil observasi yang telah dilakukan dapat ditunjukkan pada pembelajaran konvensional sebagai berikut: (a) Mengucapkan salam pembukan (cukup aktif), (b) Apersepsi; menjawab pertanyaan dosen (cukup aktif), (c) Menyimak penyampaian tujuan pembelajaran (cukup aktif), (d) Menyimak pemberian pengantar materi oleh dosen (cukup aktif), (e) Mengikuti pemberian materi oleh dosen (cukup aktif), (f) Partisipasi mahasiswa (kurang aktif), (g) Memberikan simpulan (kurang aktif), (h) Evaluasi; menjawab pertanyaan dosen (kurang aktif), (i) Refleksi; memberikan tanggapan (kurang aktif), dan (j) Menjawab salam penutup (cukup aktif). Dari peniliaan tersebut dapat digambarkan pada Tabel berikut.

Tabel 4. Hasil

ObservasiPembelajaranmelaluiPenerapan Model PembelajaranKonvensional

\begin{tabular}{|c|c|c|c|c|c|}
\hline \multirow[b]{2}{*}{ Soal } & \multicolumn{5}{|c|}{ PilihanJawaban } \\
\hline & $\begin{array}{l}\text { SA } \\
(5)\end{array}$ & $\begin{array}{c}A \\
(4)\end{array}$ & $\begin{array}{c}\text { CA } \\
(3)\end{array}$ & $\begin{array}{c}\text { KA } \\
\text { (2) }\end{array}$ & $\begin{array}{l}\text { TA } \\
\text { (1) }\end{array}$ \\
\hline 1 & & & 3 & & \\
\hline 2 & & & 3 & & \\
\hline 3 & & & 3 & & \\
\hline 4 & & & 3 & & \\
\hline 5 & & & 3 & & \\
\hline 6 & & & & 2 & \\
\hline 7 & & & & 2 & \\
\hline 8 & & & & 2 & \\
\hline 9 & & & & 2 & \\
\hline 10 & & & 3 & & \\
\hline Total & - & - & 18 & 8 & - \\
\hline \multicolumn{6}{|c|}{ Skor Total26 } \\
\hline \multicolumn{6}{|c|}{ Persentase $26 / 50 * 100=52$} \\
\hline
\end{tabular}

Berdasarkan Tabel 4 di atas, diperoleh hasil yakni 6 soal menjawab cukup aktif dengan skor 3 , dan 8 soal menjawab kurang aktif dengan skor 2 sehingga total skor 26. Dari total skor tersebut diperoleh persentase yaitu total skor dibagi skor maksimal dikali 100 menjadi: $26 / 50 * 100=52 \%$ dengan kategori cukup aktif.

\section{Simpulan}

Berdasarkan hasil penelitian dan pembahasan yang telah diuraikan di atas, terdapat beberapa hal yang menjadi simpulan dalam penelitian ini. Pertama, partisipasi mahasiswa dalam mengikuti proses pembelajaran menggunakan model pembelajaran jigsaw cenderung aktif, hal tersebut dikarenakan pembelajaran telah dirancang untuk meningkatkan partisipasi aktif mahasiswa. Kedua, pembelajaran yang telah dirancang oleh dosen mampu meningkatkan partisipasi aktif mahasiswa hal tersebut ditunjukkan oleh hasil observasi oleh dosen observer yang memberikan penilaian sebesar 96\% (kategori sangat aktif), dan penilaian mahasiswa sebesar $82,14 \%$ (kategori sangat aktif). Ketiga, pada model pembelajaran konvensional tingkat partisipasi aktif mahasiswa cenderung rendah, hal tersebut dikarenakan pembelajaran pada siang hari di mana fokus mahasiswa telah mulai berkurang. Keempat, pembelajaran konvensional yang telah dirancang oleh dosen masih belum memunculkan partisipasi aktif mahasiswa, hal tersebut ditunjukkan oleh hasil observasi oleh dosen observer yang memberikan penilaian sebesar 52\% (kategori cukup aktif), dan penilaian mahasiswa sebesar $45,31 \%$ (kategori cukup aktif).

\section{Saran}

Berdasarkan hasil penelitian yang telah dilakukan, peneliti dapat memberikan saran sebagai berikut: (1) penentuan jadwal perkuliahan untuk mata kuliah teori sebaiknya dialokasikan pada pagi hari di mana fokus dan konsentrasi mahasiswa masih tinggi, (2) pengembangan model pembelajaran selanjutnya untuk peningkatan kualitas pembelajaran, (3) pemberian ice breaking pada siang hari 
untuk menstimulasi mahasiswa sehingga partisipasi aktif mahasiswa dapat tetap terjaga.

\section{Ucapan Terimakasih}

Penulis mengucapkan terima kasih kepada Belmawa Kemenristekdikti melalui program Penugasan Dosen ke Sekolah (PDS) Implementasi di Perguruan Tinggi yang diberikan kepada Fakultas Keguruan dan Ilmu Pendidikan, Universitas Musamus tahun 2019. Penulis juga mengucapkan terima kasih kepada Rektor Universitas Musamus, Dekan Fakultas Keguruan dan Ilmu Pendidikan Universitas Musamus, dan juga Ketua Jurusan Pendidikan Guru Sekolah Dasar, Fakultas Keguruan dan Ilmu Pendidikan Universitas Musamus yang telah memfasilitasi penulis untuk melaksanakan implementasi PDS.

\section{Daftar Pustaka}

[1] Sunhaji, "KONSEP MANAJEMEN KELAS DAN IMPLIKASINYA DALAM PEMBELAJARAN," $J$. Kependidikan, vol. 2, no. 2, pp. 3046, 2014.

[2] A. Pane, "Belajar dan Pembelajaran," FITRAH J. Kaji. Ilmu-ilmu Keislam., vol. 3, no. 2, 2017.

[3] A. A. Hurit and D. Harmawati, "Analisis Kesiapan Guru dalam Mengimplementasikan Kurikulum 2013 di SD Inpres Gudang Arang Merauke," Musamus J. Prim. Educ., pp. 116-123, Apr. 2019.

[4] Pardjono, "Konsepsi Guru Tentang Belajar dan Mengajar dalam Perspektif Belajar Aktif," J. Psikol., no. 2, pp. 73-83, 2000.

[5] B. Widuroyekti, "Pendekatan Belajar Aktif dan Peningkatan Partisipasi Mahasiswa dalam Proses Tutorial Tatap Muka," J. Pendidik., vol. 7, no. 1, pp. 55-65, 2008.

[6] M. Palobo and Y. Tembang, "ANALISIS KUALITAS RANCANGAN PENELITIAN TINDAKAN KELAS GURU,"
MAGISTRA J. Kegur. dan Ilmu Pendidik., vol. 6, no. 2, pp. 119-128, Sep. 2019.

[7] C. Fitriani, M. AR, and N. Usman, "Kompetensi Profesional Guru Dalam Pengelolaan," J. Magister Adm. Pendidik. Pascasarj. Univ. Syiah Kuala, vol. 5, no. 2, pp. 88-95, 2017.

[8] M.

Nurtanto,

"MENGEMBANGKAN

KOMPETENSI

PROFESIONALISME GURU DALAM MENYIAPKAN

PEMBELAJARAN YANG BERMUTU," Pros. Semin. Nas. Inov. Pendidik., vol. 0, no. 0, Aug. 2016.

[9] D. Hasmidyani, "Upaya Meningkatkan Partisipasi dan Hasil Belajar Mahasiswa Melalui Tipe NHT (Numbered Heads Together)," J. Pendidik. Progresif, vol. 5, no. 1, pp. 45-60, 2015.

[10] N. Martono, "Upaya Peningkatan Partisipasi Mahasiswa dalam Proses Pembelajaran Mata Kuliah Sosiologi Pendidikan melalui Metode Peer Teaching dan Brainstorming," $J$. Pendidik. dan Kebud., vol. 14, no. 75, 2008.

[11] L. Safrida, R. Ambarwati, and E. Albirri, "Partisipasi Mahasiswa dalam Pembelajaran Kooperatif Berdasarkan Lesson Study," J. Edukasi, vol. 4, no. 3, pp. 54-58, 2017.

[12] A. K. Hidayat, "MENINGKATKAN PEMAHAMAN MASSAGE MELALUI METODE KOOPERATIF TIPE JIGSAW PADA MAHASISWA PJKR ANGKATAN 2012 UNIVERSITAS MUSAMUS," Magistra J. Kegur. dan Ilmu Pendidik., vol. 3, no. 2, pp. 105-115, Jul. 2016.

[13] R. Untarti and A. B. Kusuma, "Meningkatkan Partisipasi Aktif Mahasiswa Melalui Lesson Study pada Mata Kuliah Geometri Ruang," 
Jurnal Edumaspul, 4 (2), Year 2020- 139

(Agus Kichi Hermansyah*, Dewi Puji Rahayu, Ratna Purwanty, Yonarlianto Tembang)

J. Pendidik. Mat. dan IPA, vol. 9, no. 1, 2018.

[14] W. N. Yanuarto, "DESKRIPSI PARTISIPASI AKTIF, DAN KEMAMPUAN KOMUNIKASI MATEMATIS MAHASISWA PADA MATA KULIAH GEOMETRI ANALITIK BIDANG MELALUI PENERAPAN LESSON STUDY," KHAZANAH Pendidik., vol. 8, no. 2, Mar. 2015.

[15] A. K. Hermansyah, "MEDIA PEMBELAJARAN PENGHANTAR BERPOLA PIKIR GLOBAL Instructional Media As Conductor To Global Mindset," Pros. Semin. Nas. II Tahun 2016, Kerjasama Prodi Pendidik. Biol. FKIP dengan Pus. Stud. Lingkung. dan Kependud. Univ. Muhammadiyah Malang Malang, 26 Maret 2016, pp. 198212, 2016.

[16] L. J. Moleong, Metode Penelitian Kualitatif. Bandung: Usaha Nasional, 2002.
[17] Sugiono, Metode Penelitian Kuantitatif, Kualitatif, dan $R \& D$. Bandung: Penerbit Alfabet, 2016.

\section{Profil Penulis}

Agus Kichi Hermansyah, lahir Lampung, 15 Agustus 1989, S1 Universitas Cenderawasih Program Studi Pendidikan Guru Sekolah Dasar lulus tahun 2012, S2 Universitas Negeri Malang Prodi Pendidikan Dasar konsentrasi Pendidikan Bahasa Indonesia Pendidikan Dasar lulus tahun 2017. Pernah mengajar di Sekolah Dasar Cenderawasih Merauke tahun 20092010, SMA KPG Khas Papua Merauke, 2012-2014, SMK Kesehatan Yaleka Maro Merauke tahun 2013-2014, dan mulai Agustus 2014 hingga saat ini aktif sebagai Dosen pada homebase di Jurusan Pendidikan Guru Sekolah Dasar, Fakultas Keguruan dan Ilmu Pendidikan, Universitas Musamus. 